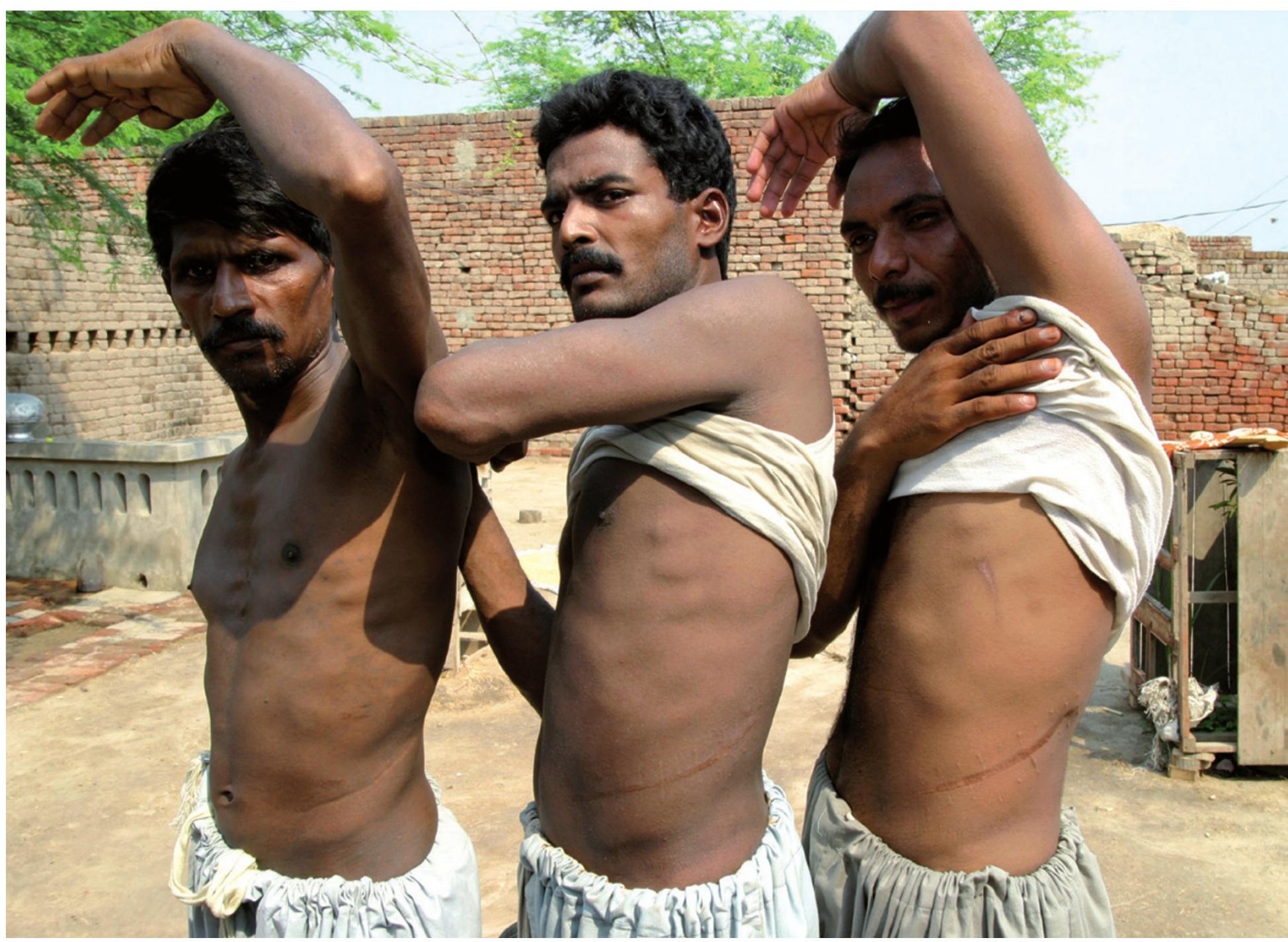

Three Pakistani men show their scars from selling a kidney — such organ donation was banned in the country in 2007.

\title{
Battling the body brokers
}

\section{A hard-hitting book calls for greater transparency to deter the illegal trade in human blood, organs and eggs, finds Laura Spinney.}

Y ou've heard of the black market. Now here's the The Red Market, a book describing the global trade in body parts and people that props up the health, fertility and adoption industries. In his exposé of the crimes and human-rights violations that are committed to supply the trade, investigative journalist Scott Carney probes a business that is now "larger, more pervasive, and more profitable than at any other time in history". The World Health Organization estimates that $10 \%$ of world organ transplants are obtained illegitimately; Carney argues that it is a good rule of thumb for estimating exchanges of all body parts.

Blood, organs and children have long been traded. Thanks to globalization and advances in technology, so too now are human eggs and surrogate wombs. Carney describes two factors that red markets have in common: first, the transaction is not over when the money changes hands because buyer and seller become biologically linked; and second, because people are squeamish about swapping flesh for money, those buying the human parts tend to describe the exchange euphemistically

in terms of altruism - they receive 'donations'.

As there is not enough altruism in the world to supply the insatiable demand for body parts, morally dubious or criminal elements step in. Carney investigates, for example, how the human egg trade in Cyprus exploits poor women from east-

\section{$\rightarrow$ NATURE.COM} For more on medical ethics and clinical trials:

go.nature.com/epaixl ern Europe. He also uncovers and carries the distressing news from India to the United States that the adopted son of a 


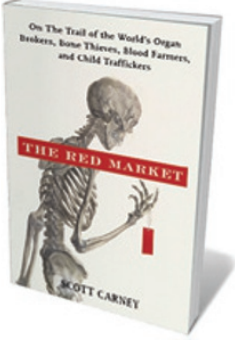

The Red Market: On the Trail of the World's Organ Brokers, Bone Thieves, Blood Farmers, and Child Traffickers

SCOTT CARNEY

William Morrow: 2011.

272 pp. $\$ 25.99$

Nepal border, where imprisoned poor Nepalese refugees and literally bled them dry, prompting Carney to delve further into India's murky blood trade.

The Red Market is an excellent piece of reporting, but the book is framed around a flawed concept. Carney describes the "specialness" that defines a living person. "There is a clear difference between the living and the dead and that specialness whatever it may be - is the rock that I've built this book upon," he writes. But there is no such division: death is a process, not an event. Over the centuries, the arbitrary line that society has drawn between life and death has shifted.

\section{DRAWN OUT DEATH}

It used to be that the heart had to stop beating before death could be declared. Now brain death is the usual criterion, and a dead person's heart can continue to beat for a while. As death encroaches on life, more and more people are considered to be eligible for organ harvesting. Carney does not specifically mention this trend, but it inevitably affects organ supply.

He does, however, allude to the blurring between life and death by describing the trade in a waste product: human hair. Although hair contains DNA, it hardly represents a biological link between donor and wig-wearing recipient, thus failing to satisfy one of his red market factors. It still meets the other criterion: the hair is 'donated', while increasing sums are exchanged for it as it moves up the supply chain.

Temple-goers in Tirupati, India, have their heads shaved for religious reasons, and are not paid for the raw material that ends up in expensive salons in Brooklyn. Likewise, in many countries, women who 'donate' their eggs are prohibited from receiving payment beyond their expenses. Organs too are given away, while every physician, nurse and health coordinator

\section{Books in brief}

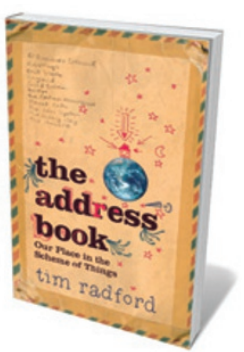

The Address Book: Our Place in the Scheme of Things

Tim Radford FOURTH ESTATE 272 pp. £16.99 (2011)

As children, many of us will have written down a long version of our address - with our street, home town and country followed by planet Earth, the Solar System, the Universe. In his latest book, science journalist Tim Radford muses on our relationship with locations at increasing scales, asking how they become part of our identities and why we make strong associations with certain places. Starting with his perspective on his possessions, house and town, Radford's horizons expand to encompass the place of humans on the planet, in our Galaxy and in the Universe.

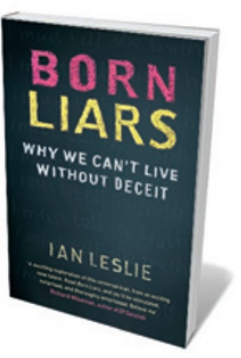

Born Liars: Why We Can't Live without Deceit

lan Leslie QUERCUS 352 pp. £12.99 (2011)

Most people say they dislike liars, but we have all told untruths. We may consciously tell a white lie, assuring a friend that an outfit suits them when we know it doesn't. Or we may fool ourselves by adhering to unrealistic beliefs, such as that we will always be healthy so it is fine to smoke. But lies are not necessarily bad, says writer lan Leslie. Although most people feel psychological discomfort when they tell falsehoods, deceit has positive benefits. As well as playing a part in advertising, politics, sport and war, it is central to human character, he argues, and has evolutionary advantages.

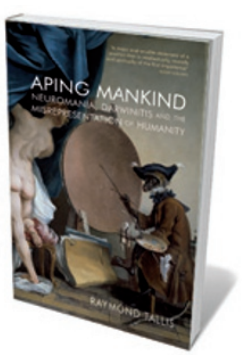

Aping Mankind: Neuromania, Darwinitis and the Misrepresentation of Humanity

Raymond Tallis ACUMEN 416 pp. £25 (2011)

Human consciousness and behaviour are more complex than can be explained by our brains alone, argues clinical neuroscientist Raymond Tallis in his provocative book. Although he acknowledges that neuroscience has made great strides in recent decades towards understanding how the brain works, he suggests that some scientists have over-reached themselves in believing that everything from art to religious belief can be explained in neural terms. Such 'neuromania' is misleading, he believes.

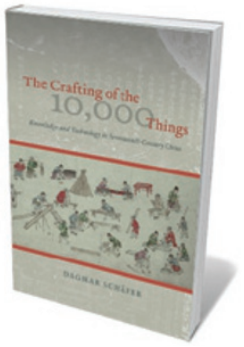

The Crafting of the 10,000 Things: Knowledge and Technology in Seventeenth-Century China

Dagmar Schäfer UNIVERSITY OF CHICAGO PRESS 352 pp. \$45 (2011)

The demise of China's Ming Dynasty in the seventeenth century was accompanied by a surge in publications detailing the state of knowledge and technology. One of the most significant was Song Yingxing's 1637 volume Tiangong kaiwu, or The Exploitation of the Works of Nature. It documented the production of materials and goods, from yeast, wine and ink to paper, boats and firearms. In this book, historian Dagmar Schäfer sets Song's encyclopedia within the broader commercial and cultural context of Ming China.

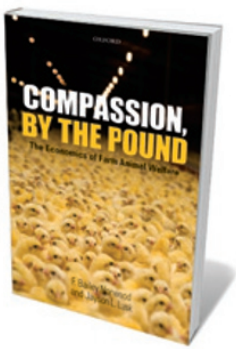

Compassion, by the Pound: The Economics of Farm Animal Welfare F. Bailey Norwood and Jayson L. Lusk OXFORD UNIVERSITY PRESS 416 pp. $\$ 45$ (2011)

Economic assessments have been largely missing from debates on the welfare of farm animals. Agricultural economists Bailey Norwood and Jayson Lusk rectify that in this volume by evaluating the value of organic eggs, free-range pork and the use of antibiotics in farm animals. Consumers are willing to bear the extra costs for greater animal welfare in food production, they find, but the price in some cases is reduced efficiency, which requires more animals to be used. 
involved in transplanting them is paid for their contribution.

Because the buyers insist on using the language of gifts, the recompense for the donor - from clinics, hospitals or brokers - is tiny. So only the poor and desperate are tempted. Profiteers increase the supply through coercion.

Protecting donors' anonymity enables buyers to turn a blind eye to the source of their flesh. And as Carney puts it: "The one-two punch of anonymity and donation means that profit-taking middlemen control the entire supply chain."

The global industry in body parts exploits the varied regulations and economic conditions in different countries. The fact that body parts have often travelled across continents also obscures their source. By the time an Indian child's papers reach an adoption agency in the United States, for example, there is often no easy way of verifying whether that child was given up voluntarily.

Banning organ commerce will not help, Carney says, because the red market would be driven further underground and "Every child, the poorest would kidney or continue to supply bag of blood it in return for risshould be ible fees. Nor will labelled fully embracing with the the market work, name of the as demand will rise person who alongside supply. provided it" Physicians will find new indications for transplants as more organs become available, and as they hold out hope for ever-smaller improvements in the lives of very sick patients. A third option, to grow synthetic body parts, is appealing but remains science fiction for now.

Carney does argue that the market should be transparent, with every child, kidney or bag of blood labelled with the name of the person who provided it. The supply pool might shrink, but the criminal middlemen would be eliminated. The richer members of society - those creating most of the demand - could also learn to accept their mortality, and to question whether, in every case, the extended life that a transplant promises is worth the human suffering it costs farther back along the chain. It's not much of a sticking plaster, but The Red Market is a reminder that there are some problems that science alone cannot solve.

Laura Spinney is a writer based in Lausanne, Switzerland. e-mail:1fspinney@gmail.com

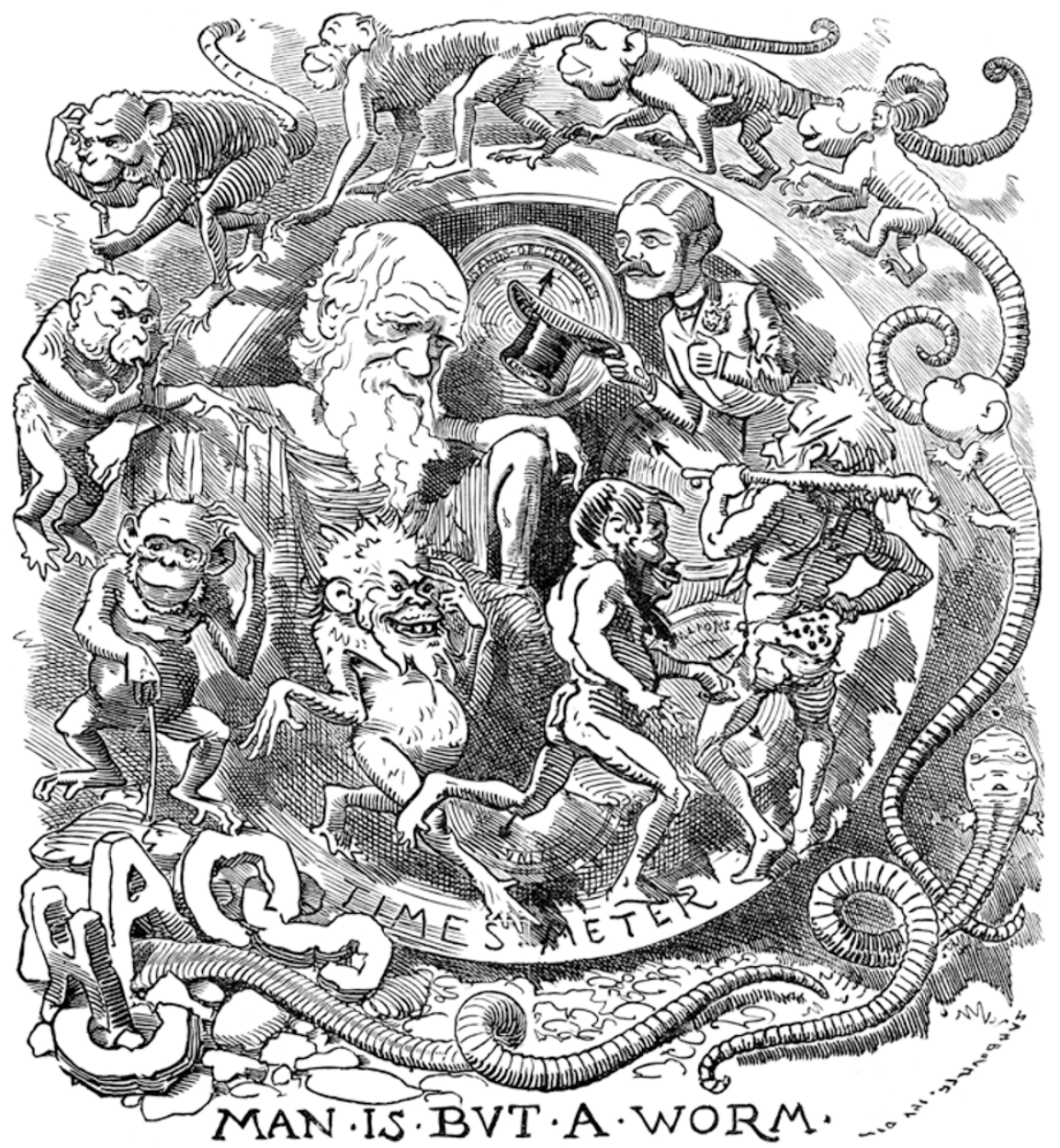

An 1881 Punch cartoon satirizing Charles Darwin's body of work that connected humans with worms. EVOLUTION

\section{Darwin's other books}

\section{From geology to mould, the naturalist's publications form a coherent whole, finds Eugenie Scott.}

$\mathrm{M}$ ost people are familiar with On the Origin of Species, but few are aware of Charles Darwin's decades of productive work before and after its publication. Indeed, creationists present Darwin as a one-trick pony: a rich dilettante who loafed around his country manor until he stumbled across evolution by natural selection. So I was delighted to read Steve Jones's The Darwin Archipelago (published in Britain as Darwin's Island), an entertaining and thoughtful treatment of Darwin's other books.

Darwin was a respected scientist - and a recipient of the Wollaston Medal, the Geological Society of London's highest award - well before the Origin's publication in 1859. By then, he had eight books to his name, starting with The Voyage of the Beagle in 1839 and followed by three volumes on geology and four on barnacles. Ten further books and monographs appeared after the Origin, including The Formation of Vegetable Mould, through the Action of $\underset{\varpi}{\stackrel{4}{~}}$ Worms, which was published in 1881, the year before his death at the age of 72 .

As in his earlier treatment of the Origin, titled Almost Like a Whale (published in the United States as Darwin's Ghost), Jones shows how Darwin's ideas have inspired and been augmented by subsequent research. And Jones shows his flair for a one-liner: a worm is an "animated intestine", and molecular biology is "no more than comparative anatomy plus a mountain of cash".

Jones notes that all of Darwin's work $\rightarrow$ NATURE.COM

For more, see Nature's Darwin 200 special issue: nature.com/darwin 